meteorological interest, among them being that of the date and type of the onset of the south-west monsoon along the west coast of India and of the evidence for the influence of afforestation on climate in the Singhbhum District. A notable result of the Section's activity in liaison between meteorology and agriculture can be seen in Appendix I of this report, which is a long list of experimental farms at which meteorological instruments have been installed, with details of each lay-out.

\section{Timber Utilization in Malaya}

Malayan Forest Records No. 13 (Caxton Press, Ltd., Kuala Lumpur, 1940), by H. E. Desch and A. V. Thomas, is not intended to replace the standard text-books, but to provide local timber users with a minimum of information necessary for the correct use of Malayan timbers under Malayan conditions. The paper, which is fully illustrated, deals with the subject on the well-known lines of : anatomical structure of wood, identification and classification of Malayan timbers, seasoning, defects, preservation, mechanical properties of timber, and design in relation to correct utilization of timber in new buildings. The authors have commenced their work by giving an account of the forest administration, climatic factors, types of forest, timber resources and forest policy of Malaya, sylvicultural operations, timber requirements of the future, exploitation, methods of extraction, and financial aspects--somewhat unusual information to find incorporated in what is admittedly a handbook for timber users. The authors make a noteworthy admission. As a result of their investigations-and they have had predecessors in India-they state that in connexion with the tropical and semi-tropical forests it is not possible to draw a hard-and-fast line between the commercially productive and the protection forests; nor is it possible to calculate with any degree of accuracy the potential annual production of timber to be obtained from these types of virgin forest. The volumes per unit of area obtainable from the latter bear no relation to an equivalent area of commercial forest in temperate regions.

\section{Protection of Buried Electrical Cables}

Is the Bell Laboratories Record of January, Mr. R. P. Ashbaugh describes how the lead sheath of a buried electric cable can be protected against soil corrosion. These buried cables have been used extensively in rural areas instead of aerial cables for several years. In several localities in the United States, cases have frequently occurred where small rodents such as gophers have gnawed the cables, puncturing the sheath and so letting in moisture, which ruins the insulation. Two layers of substantial steel tape protect the cable conductors against inductive interference from power lines and also against gophers, but they are expensive, and a cheaper construction was therefore sought. The construction adopted consists of a single overlapping layer of impregnated paper, a single layer of thin steel tape applied helically with just sufficient gap to allow for normal bending, a second overlapping layer of impregnated paper, and one or two layers of impregnated jute roving. Floodings of asphalt compounds are applied over the sheath and over each protective layer of paper and jute. About 130 miles of this new construction has been furnished for the buried portion of the Stevens Point - Minneapolis cable, and a considerable number of small orders for territories that are gopher-infested have also been manufactured and installed.

\section{The Stockholm Technical Museum}

The Tekniska Museet of Sweden has recently been installed in new buildings in Stockholm, erected with funds provided by the Knut and Alice Wallemburg Foundation. The Museum was originally opened in 1923, and it has been assisted by many industrial companies and private persons. In view of the important contributions to engineering, metallurgical and chemical progress by many eminent Swedes, the Museum should prove a worthy addition to such institutions. There will be a Hall of Fame and in this will be the busts of Polhem, Swedenborg, Celsius, Angström, Rinman, John Ericsson, Carlund, Nobel, De Laval, Wenstrom, Brinell and others. An outstanding exhibit is an original tower clockwork shown running, designed and built by Polhem. It was moved to the Museum from St. Mary's Church in Stockholm, where it had been running from 1765 until 1910.

\section{Vital Statistics of London County Council}

The interim report of the London County Council Medical Officer of Health and School Medical Officer for the year 1939 contains the following information : The residential population for the middle of 1939 was $4,013,800$, as compared with $4,062,800$ at the middle of 1938 . The marriages registered in London during 1939 numbered approximately 54,461, or $27 \cdot 1$ persons married per thousand of the population. The live births allocated to London during 1939 were approximately 52,366 , as compared with 54,495 in the previous year. The live birth-rate was 13.0 per thousand, the rate for 1938 being $13 \cdot 4$. The deaths in the total population of London during 1939 numbered 46,377, giving a death-rate of $12 \cdot 3$ per thousand, as compared with 11.4 in 1938. Of the total deaths 22,554 , or $48 \cdot 6$ per cent, were among females. There was an increase in the number of fatal street accidents-from 363 in 1938 to 519 in 1939. The deaths under one year of age per thousand live births were 47 , compared with 57 in the preceding year. This constitutes a new low record.

\section{Dr. Heinrich Kisch}

Dr. ENoch Heinrich Kisch, an eminent balneologist and gynæcologist, was born on May 6, 1841, at Prague, where he received his medical education and qualified in 1862. In the following year he settled in Marienbad as a balneologist, and largely contributed to making that town a health resort. In 1867 he was appointed lecturer, and in 1884 extraordinary professor in balneotherapy, at the medical faculty of Prague. In 1868 he became editor of the Allgemeine balneologische Zeitschrift, and later of the Jahrbïcher 
für Balneologie. His principal original works in balneology were "Handbuch der allgemeinen und speciellen Balneotherapie" (third edition, 1875) and "Grundriss der klinischen Balneotherapie" (1897), while his chief gynæcological publications, in order of their appearance, were "Über den Einfluss der Fettleibigkeit auf die weiblichen Sexualorgane"(1873), "Das klimakterische Ältern der Frau" (1874), "Die Sterilität des Weibes" (1895), and "Geschlechtsleben des Weibes in physiologischer, pathologischer und hygienischer Beziehung" (1904), which was translated into English by M. Cedar Paul in 1910 under the title of "The Sexual Life of Woman". An autobiographical work entitled "Erlebtes und Erstrebtes: Erinnerungen" appeared in 1914. He died at Marienbad on August 24, 1918.

\section{Gustave Le Bon}

Dr. Gustave Le Bon, a prominent psychologist, ethnologist and natural philosopher, was born at Nogent Le Notru, Eure-et-Loire, on May 7, 1841. He started his career as a medical officer in the French Army and served in the Franco-Prussian War of 1870-71, but afterwards gave up the practice of medicine and travelled extensively in Europe, Africa and Asia. In 1884 he was ordered by the French Government to report on the Buddhist monuments in India. The results of his investigations were published in "La Civilisation de l'Inde" (1884) and "Les Monuments de l'Inde" (1894). He is best known, however, for his works on psychology, especially "La Psychologie des foules" (1895), which went through twenty-seven editions and was translated into many foreign languages. $\mathrm{He}$ also wrote on psychology in relation to the French Revolution, the War of 1914-18, socialism and education. His chief contributions to natural philosophy consisted in his "Evolution de la matidre" (1905) and "Evolution des forces" (1907). An anatomical and mathematical study on variations in the size of the cranium won him a prize from the Paris Academy and the Anthropological Society of Paris. He was founder and for some years director of the Bibliothèque de philosophie scientifique. $\mathrm{He}$ died on December 14, 1931.

\section{Announcements}

Pror. A. V. HIrL, M.P., one of the secretaries of the Royal Society, has been elected a foreign associate of the U.S. National Academy of Sciences.

Ar a recent meeting of the official and family trustees of the British Museum, Cardinal Hinsley, Archbishop of Westminster, and Sir William Bragg, director of the Royal Institution, were elected to the Trust.

Dr. E. L. Kennaway, of the Royal Cancer Hospital, London, and Dr. J. W. Cook, regius professor of chemistry in the University of Glasgow, have been awarded the annual Katherine Berkan Judd prize of a thousand dollars by the Memorial Hospital for the Treatment of Cancer and Allied Diseases, for outstanding contributions to the knowledge of the cause and cure of cancer during 1939 and 1940.
A Decres depriving Mlle. Eve Curie of French citizenship and confiscating her property was signed by Marshal Pétain in Vichy on May 5.

AT the anniversary meeting of the members of the Royal Institution held on May 1, the following officers were elected : President, Lord Eustace Perey; Treasurer, Sir Robert Robertson; Secretary, Major Charles E. S. Phillips.

A NEW institute of hygiene and medical chemistry has recently been established at Göttingen.

AT the recent meeting of the Indian Science Congress at Benares, the Indian Society of Genetics and Plant Breeding was inaugurated. The following officers were elected for the year 1941: President, Rao Bahadur T. S. Venkatraman; Vice-Presidents, Dr. W. Burns, Mr. K. Ramiah ; Secretary, Dr. B. P. Pal ; Treasurer, Dr. S. Ramanujam; Councillors, Dr. V. K. Badami, Dr. B. S. Kadam, Dr. J. S. Patel, Dr. T. S. Sabnis. The Society will publish a journal in which papers on genetics, plant breeding and cytology will be published.

A MEETING for the inauguration of a Radiography Group of the Institute of Physics will be held at 6.0 p.m. on May 20, in the Lecture Hall of Messrs. Kodak, Ltd., Harrow. All who are interested in the uses of X-rays in industry, whether members of the Institute of Physics or not, are invited to attend.

THE following awards for 1940 of the Institution of Mining and Metallurgy have recently been announced : Consolidated Gold Fields of South Africa Limited Gold Medal to Mr. C. R. Julian for his paper on "Underground Mining at Rio Tinto, Spain"; Consolidated Gold Fields of South Africa Limited Premium of forty guineas conjointly to Mr. J. Spalding and Mr. T. W. Parker for their paper on "Air-Conditioning Plant at the Ooregum Mine-Kolar Gold Field"; William Frecheville Students' Prize of ten guineas conjointly to Mr. J. E. Denyer and Mr. K. C. G. Heath for their paper on "Mining and Milling Tin-Tungsten Ore at Mawchi Mine, Burma". The Council has also elected Mr. H. K. Picard to honorary membership, in recognition of his distinguished services to metallurgy.

Messrs. Charles Baker, of 244 High Holborn, London, W.C.1, are desirous of making an appeal to readers of NATURE to offer for sale certain apparatus which they are able to release for work of national importance. The whole of the British scientific industry is engaged on the production of apparatus for war purposes, the result being that the supply of instruments required for research, education and routine inspection work is severely limited. The demand for such instruments is constant, and increasing from every quarter, not only from official sources, but also from the industries engaged on work of the greatest importance. The following apparatus is of special interest : microscopes, optical equipment and accessories, telescopes, balances, spectrometers, refractometers, surveying apparatus, slide rules and drawing instruments. 